\title{
EXPLORING INTEGRATIVE CREATIVE LEADERSHIP IN THE FILMMAKING INDUSTRY
}

\author{
Nicole Flocco(1), Filomena Canterino(1), Stefano Cirella(2), Jean-Francois Coget(3), Abraham \\ B. (Rami) Shani(3) \\ (1) Department of Management Engineering, Politecnico di Milano, Italy \\ (2) Essex Business School, University of Essex, United Kingdom \\ (3) Orfalea College of Business, California Polytechnic State University, CA, United States \\ Corresponding author: Nicole Flocco, via Lambruschini 4B, 20156 Milan, Italy \\ nicole.flocco@polimi.it, +390223994759
}

\begin{abstract}
This chapter elaborates on Mainemelis, Kark, and Epitropaki's (2015) multi-context model of creative leadership. More specifically, we focus on integrative leadership, one of the three contexts outlined in the model. Integrative leadership is a context in which multiple non-similar professionals provide highly heterogeneous inputs that need to be integrated. How the integration occurs, though, is still not fully understood. We therefore explore how integrative leadership occurs in the filmmaking industry through examples from six renowned film directors. In this position paper, we hypothesize that directors vary considerably in the extent to which they practice integration in an autocratic vs. a democratic manner. Furthermore, we hypothesize seven factors related to variation along that continuum: (1) The personality of the director, in particular, their apparent need for control; (2) The temporality of involvement of others in crafting the vision: early vs. late; (3) Secrecy, or the extent to which directors protect the creative process from others vs. leave it open; (4) Directors' tendency to work with the same crew and cast across different movies or not; (5) Consolidation of roles by the director; (6) Technology; and (7) The organization of the filmmaking process.
\end{abstract}

KEYWORDS Leadership, creative leadership, creativity, integrative creative leadership, filmmaking industry, movie directors 


\section{INTRODUCTION}

Creativity - defined as "the production of ideas, products, or procedures that are novel or original, and potentially useful or practical" (Amabile, 1996) or "as a continuous process of thinking innovatively, or finding and solving problems, and implementing new solutions" (Basadur, Graen \& Green 1982) - is considered a necessary prerequisite for organizational innovation, growth, and survival. Many scholars assert that leadership plays a crucial role in managing the creative process and that it is unlikely that creative outcomes will be realized without a large degree of support from organizations and organizational leaders (Reiter-Palmon, \& Illies, 2004).

Various studies have examined the relationship between leadership and creativity (e.g. Lovelace and Hunter, 2013; Mumford et al., 2012; Zhang and Bartol, 2010, Harris et al., 2013; Murphy and Ensher, 2008). A recent contribution about these topics came from Mainemelis, Kark, and Epitropaki (2015), who surveyed and analyzed the dispersed body of knowledge about leadership and creativity and synthesized it under the construct of creative leadership. In their work, Mainemelis et al. (2015) suggest three narrow conceptualizations of creative leadership, related to: (i) facilitating employee creativity, (ii) directing the materialization of a leader's creative vision, and (iii) integrating heterogeneous creative contributions. These three manifestations of creative leadership represent collaborative contexts in which leaders and followers interact in the creative process. The three contexts differ in terms of creative contributions (e.g. generating and developing new ideas) made by the leader and those made by the followers; and also in terms of supportive contributions (e.g. providing psychological, social and material support for creativity) made by the leader and by the followers. 
In the Facilitating context, leaders themselves have limited creative contributions. Their focus is on supporting and enabling employee creativity. This is radically different from directive contexts, in which the leader is the key creative agent, and employees' role is to facilitate and execute the leader's creative vision. Integrating heterogeneous creative contributions represents a third context, where non-similar professionals typically collaborate in order to integrate highly heterogeneous inputs. In this third context, both leaders and followers are creative in their own right, and play an important, distinctive, and often credited role, in the creative process. However, the process is so complex that it needs to be coordinated by the leader so that the different contributions form an integrated whole. This third context is the focus of this manuscript.

Filmmaking is typical of integrative creative leadership, a context in which multiple nonsimilar professionals provide highly heterogeneous inputs. Films require a screenwriter, a director, a director of photography (who operates and directs camera and lighting equipment), a sound editor, actors, a music composer, a special effects director, an editor, and many other such professionals as set designers, costume designers, ADs (assistant directors), location scouts, producers, casting directors, make-up artists, PAs (personal assistants), etc. (Bechky, 2006; Coget, 2004). A key role of the director is to elicit, orient, and integrate the heterogeneous inputs of these various professionals into a coherent whole, the final cut. Integrating is both a leadership and a creative activity. The director is typically the one who provides the artistic vision for the movie, a creative product itself. The creative vision is also a tool that influences and aligns other professionals' creative processes, so as to prepare the integration of their products into the whole. 
Integration occurs, for instance, in the collaboration between the director and his or her actors. While actors bring their own skill, training, and acting philosophy or method to the table, and are selected partly for it, the director is supposed to "direct" them. This involves having a number of preparatory discussions with them, and providing them with subtext, notes, adjustments and other prompts, sometimes in between different takes, to bring their character to life, according to the director's vision, but also the actors' vision. Power struggles between actors and directors are not rare.

Likewise, the director works intimately with their Director of Photography (DP) to craft visual looks and effects. Camera angles, movement, and other choices are essential to the look of a movie. The editor is another crucial partner; selecting, cutting, and stitching together takes to create different cuts that tell the story visually. Music is essential to creating the emotional mood and tonality of a movie. Directors often collaborate with composers to craft music that reflects the mood they intend to create. The script is the core of a movie, and typically written entirely prior to the filming of a movie. Sometimes the director writes the script, or collaborates with the screenwriter before, and even during filming to rewrite the script.

Some professional inputs are arguable more important than others. The DP and principal actors, for instance, arguably weigh more heavily on the final product than make-up artists or even set and costume designers. Nonetheless, each professional has some input that needs to be integrated into the whole. Mainemelis et al. (2015) emphasize integration as a key role of creative leaders in the "integrative leadership context." In filmmaking, this role falls upon the director. 
How do directors do it? More specifically, to what extent do they involve others in the process of integration? While the final product is a collective effort, the act of integrating heterogeneous inputs itself is not necessarily so. At the limit, integration could be done solely by the director, in an autocratic manner. At the other end of the spectrum, it could be shared with others, in a more democratic manner.

This position paper explores variation along these two extremes: autocratic vs. democratic integration, through examples from different, famous directors. Some directors, such as Lars Von Triers, are known to be "control freaks", who attempt to micromanage all aspects of filmmaking, and are even reluctant to credit other people's inputs. Others, such as Richard Linklater, are known to collaborate extensively with their crew and cast, often writing the script, even the concept of the movie itself, with his actors, and collaborating with the same, intimate crew repeatedly. Through a few illustrative examples, we develop hypotheses about the factors that influence the extent to which directors share the burden of integration in filmmaking.

\section{APPROACH}

We chose to focus our study on the filmmaking industry because, while directors are undoubtedly the leaders of the creative process, having the greatest creative influence on films, filmmaking nonetheless demands a high degree of creative collaboration, with various professionals making distinct, credited creative contributions. The job of a movie director requires strong creative skills and a creative vision. It also demands leadership skills, such as the ability to inspire and integrate high-magnitude creative contributions from various other professionals. Indeed, Mainemelis et al. (2015) identify filmmaking as an exemplar of the integrative context. 
Having narrowed down our exploration to filmmaking, we chose to investigate movie directors that seemed to vary maximally on our variable of interest: the extent to which they integrate creative contributions among their team in an autocratic vs. a democratic manner. This led us to investigate six renowned movie directors who seem to vary considerably on that continuum: Christopher Nolan, George Lucas, John Lasseter, Lars von Trier, Quentin Tarantino, and Richard Linklater. In particular, this selection was based on three criteria: (i) we chose directors who also wrote the screenplay of their movies, so as to follow the creative process from the earliest stage of idea generation; (ii) we included directors who produced several successful, internationally recognized movies, including prequel/sequel, sagas and animated films, which require the management and coordination of a wide range of experts; (iii) we identified directors who differed from each other in terms of attitude, personal characteristics, working habits and genres of movies they typically directed. We collected and analyzed a wide array of secondary sources about these six directors: 13 videos, 4 documentaries, 39 articles, 7 interviews, and 2 books.

\section{EMERGING THEMES}

Our exploration confirmed that movie directors indeed seem to vary considerably in the extent to which they integrate various contributions in an autocratic vs. a democratic manner. Furthermore, we identified seven possible factors that appear to be associated with this variation: (1) The personality of the director, in particular, their apparent need for control; (2) The temporality of involvement of others in crafting the vision: early vs. late; (3) Secrecy, or the extent to which directors protect the creative process from others vs. leave it open; (4) Directors' tendency to work with the same crew and cast across 
different movies or not; (5) Consolidation of roles by the director; (6) Technology, in particular how high vs. low tech the movie is, as indicated by the extent and complexity of special effects or animation in the film making process; and (7) The organization of the filmmaking process, such as whether rehearsals occur or not, or time is allotted for creative reorientation during the film making. Next, we illustrate these seven factors with examples from the six directors we investigated.

\section{Personality of the director - need for control}

The personality of the director seems to influence the degree to which they integrate other professionals' contributions autocratically or democratically. Some directors seem to have a higher need for control than others. Linklater and Lasseter, for instance, seem to possess a relatively lower need for control than other directors:

"Filmmakers are control freaks. For us, it's about bending the elements of a story into existence. But you had to give up full control, and admit you have a major collaborator sitting with you at all times: that's the unknown, the future. You're counting on it being there, but you don't know what it is yet."' (Richard Linklater - Linklater's case)

"I still understand the need for faith in a creative context. Because we are often working to invent something that doesn't yet exist (...). When we trust the process, we can relax, let go, take a flyer on something radical. We can accept that any given idea may not work and yet minimize our fear of failure because we believe we will get there in the end" (coproducer - Lasseter's case)

Tarantino offers a good contrast to these, especially with respect to dialogue. He insists that actors remain absolutely faithful to his scripts:

“Actors aren't there to riff. They're there to say the dialogue. If their riffing is genius, I 
will take credit for it” (Quentin Tarantino - Tarantino's case)

Nolan and von Trier also demonstrate a high need for control:

"I almost never get to leave the set. I have to go pee sometimes, of course, but otherwise I'm there, by the camera, the whole time." (Christopher Nolan - Nolan's case)

"I like that you're at the mercy of the director and don't know where you're going." (Lars von Trier - von Trier's case)

\section{Involving others early vs. late in crafting the vision}

Creative leadership requires awareness of the temporal complexity dimensions of creative projects (Halbesleben et al., 2003, Mainemelis, 2002). In our exploration, we found indication that temporality indeed had an influence on the integrative process. More specifically, we hypothesize that how early directors involve others in crafting the vision influences the degree to which they integrate other professionals' contributions autocratically or democratically. The directors who involve others early tend to integrate more democratically. Linklater for example wrote the entire script of the movie "Before Sunset" with the two main actors, Ethan Hawke and Julie Delpy:

"Ethan and Julie brought much of themselves to [the previous] work, a lot of their ideas and story, so when the three of them [Linklater, Hawke, Deply] decided to make the second movie they wanted to come in as writers." (co-producer - Linklater's case)

Ethan Hawke commented:

"We talked about it for years and we realize we really had to do it, we all, for about a year, exchange emails, writing different scenes and say 'try to write on this subject, on that subject' and then one day Julie posted us forty pages...I was pregnant with the idea for a while." (actor - Linklater's case) 
John Lasseter, at Pixar, also integrates followers' creative contributions in the initial stages of the creative process:

"I come up with the initial concepts. We bounce the idea around with the crew we have. Most of them have computer backgrounds, but over the years they've become quite savvy with animation and stories. So we usually develop the stories together, and I'll do the storyboard. From the storyboard we define what needs to be modeled.

We generally divide up the modeling task between the crew. I'll do some modeling, and then I'll do all the animation, generally." (John Lasseter - Lasseter's case)

\section{Secrecy}

Another factor we found associated with autocratic vs. democratic integration was secrecy. Tarantino, for example, is very secretive about his scripts, and different cuts of his movies:

"The script was sent out to actors with the warning "If you show this to anybody, two guys from Jersey [Films] will come and break your legs."”' (Quentin Tarantino Tarantino's case)

Brad Pitt, in a conference press about the movie "Inglorious Bastards", declared:

"No one has seen the film yet, because Quentin kept it under wraps, so it could be very nice for us tonight to see all it together, because all we know is we wrapped three months ago. We shot our respective parts and, suddenly, here we are” (actor - Tarantino's Case)

The same thing could be said for Nolan:

"Secrecy is less of a fact on a Christopher Nolan production than it is a working method. Michael Caine was allowed to keep his script for Interstellar, but each page of every copy of the script bore his name, so it could be traced back where it to go missing" (interviewer 
- Nolan's Case)

This need for secrecy stands in stark opposition with the collaborative and sharing practices associated with a democratic creative exchange, where leaders usually rework the story and change the plot to integrating other professionals' ideas.

\section{Working with the same crew and cast across movies}

Although integrative creative leadership seems to be associated with higher degree of recombination (Mainemelis et al. 2015), some directors seem to find benefits in working with the same crew, cast, and/or producer across projects (Alvarez et al., 2005; Alvarez and Svejenova, 2002). Additionally, even though movies are typically organized as temporary projects (Bechky, 2006), some movies, such as Pixar's animations, are produced by permanent organizations, even though they are projects within the organization. We hypothesize that working with the same team across projects helps the integration and might favor a more democratic type of integration, by reducing the need to constantly communicate and clarify expectations. Nolan, for instance, worked with the same directorial team (1st AD Nilo Otero, 2nd AD Brandon Lambdin, and 2nd 2nd Greg Pawlik) on several of his films, and said:

"I rely on Nilo to keep a quiet set with no cell phones, and hopefully without making things too tense. He does a good job making people feel at ease, while also making it clear that we're going to be extremely focused on the work that's going on." (Christopher Nolan - Nolan's case)

Linklater and Tarantino also like to work with the same crew and actors:

"His collaborators often stay with him, his assistant and office manager Kirsten McMurray answered an ad for part-time work as a college student, ten years ago, and 
never left. Vince Palmo has been the assistant director on almost all his features over the past decade." (interviewer - Linklater's case)

"I had the same problem with Sam for about a decade, it's hard not to write for these guys, they say my dialogues so well...for seven months of the year and a half that I was writing Kill Bill, Bill just sounded like Sam” (Quentin Tarantino - Tarantino’s case)

Directors seem to work repeatedly with people that share similar beliefs and behaviors:

"I'm very straight with the team. And if I were to get involved in a project and feel that we weren't seeing the same film, I would run a mile" (Christopher Nolan - Nolan's case)

\section{Consolidation of roles by the director}

Consolidating roles has been well-documented in the literature as a strategy to help integration, and for an individual to increase their power (Alvarez et al., 2005; Baker \& Faulkner, 1991; Bechky, 2006; Svejenova, 2005). Our investigation yielded a number of examples of directors who consolidate different roles besides that of director, such as screenwriter or DP. Such a practice seems to favor a more autocratic approach to integration. Some directors go even further than role consolidation, and overstep the boundaries of their role into others' roles. Lars von Trier, for example, often operates the camera himself, overstepping on the responsibility of the DP. In the movie "Manderlay", for instance, he credited himself as DP, alongside Anthony Dod Mantle, the DP he had hired. When a journalist asked him how many shots of the movie he did, he answered:

“Almost all of them, actually. Anthony did one scene, I think." (Lars von Trier - von Trier's Case)

Tarantino demonstrated a similar behavior when he was reluctant to credit Roger Avary, the screenwriter, as co-writer for Pulp Fiction: 
"He didn't write the script," Tarantino says today. Avary contributed the story about the boxer, which is the centerpiece of the movie (...) After production on the movie began, Avary reportedly received a call from Tarantino's attorney, demanding that he accept a "story by" instead of a co-writer credit, so that Tarantino could say, "Written and directed by Quentin Tarantino." (...) Tarantino told him that if he didn't accept the "story by" credit, Tarantino would write his section out of the script and Avary would get nothing." (interviewer - Tarantino's case)

Christopher Nolan and George Lucas tend to master other roles as well, and generally be interested in minute details of the process:

"I'm interested in every different bit of filmmaking because I had to do every bit of it myself, from sound recording and ADR to editing and music. [my study] gave me a really good grounding in knowing overall what has to go into a film technically" (Christopher Nolan - Nolan's Case)

"I was working with a British editor and the scenes would come back, and I'd go on the weekends and look at the scenes with the editor, and they just weren't working. I was very down about the whole situation. So I went in myself on Sundays and started recutting the movie...As I started to cut the film together, I realized that I was making cuts that were, you know, a foot away from where the editor had been making them. And I had been using the same takes that I'd given him" (George Lucas - Luca's case)

\section{Technology}

Large, technology-intensive productions, such as Pixar's animated films, or specialeffects laden movies such as Star Wars, require a larger crew of highly skilled individuals, as compared to lower-tech, productions more characteristic of independent movies, or European productions. 
Lars von Trier and his film school colleagues specifically articulated a method of filmmaking, dubbed Dogma 95, that is low-tech, including using natural light instead of lighting equipment, sound being produced at the same time as images, and hand-held cameras (Lumholdt, 2003). Such rules allow for the use of a smaller crew and arguably allow the director to control more of the process than a large-scale production such as Pixar's animations, where it is impossible for the director to micromanage all aspects of the process (Catmull \& Wallace, 2014).

"Because making a movie involves hundreds of people, a chain of command is essential. But in this case, we had made the mistake of confusing the communication structure with the organizational structure. Of course an animator should be able to talk to a modeler directly, without first talking with his or her manager. So we gathered the company together and said: Going forward, anyone should be able to talk to anyone else, at any level, at any time, without fear of reprimand.” (co-producer - Lasseter's case)

"We start from the presumption that our people are talented and want to contribute. We accept that." (co-producer - Lasseter's case)

"If there was one thing we prided ourselves on at Pixar, it was making sure that Pixar's artists and technical people treated each other as equals." (co-producer - Lasseter's case)

We therefore hypothesize that the more technologically sophisticated productions, which require more skilled technicians, are more likely to lend themselves to a democratic process of integration than smaller, low-tech productions. That said, low-tech productions are not necessarily associated with autocratic integration, as shown in Linklater's example. However, we argue that this type of production allows more variability than highly technical productions. 


\section{Organization of the filmmaking process}

Movies are complex and expensive ventures. The number of professionals involved in creating one, and the equipment needed are critical and have an impact on the overall costs. For this reason, time is of the essence on a movie set. Directors typically do not have the luxury of extra time. Yet, research on creativity has emphasized the importance of improvisation (Barrett, 1998; Vera and Crossan, 2004) and play (e.g. Mainemelis \& Altman, 2010; Mainemelis \& Dionysiou, 2015) in the creative process. We hypothesize that directors who build in time for rehearsal and improvisation in the filmmaking process to practice integration in a more democratic manner. Linklater is a case in point: he often rewrites the entire script with his main actors during rehearsal time:

"He schedules a lot of rehearsal time - two solid weeks or so before production startsand goes through each scene in an open-ended way, talking about character motivations and getting actors to riff. Most of the rehearsal time is spent rewriting the screenplay, line by line, drawing out and molding his work against performers' strengths and styles. "Often what I write is incredibly 'written,' pretentious" he says. "Then it's like: How do we undercut this?" The original ideas work their way into the scene, but the language changes. By the time the cameras start rolling, the screenplay is halfway between the voice of the writer-director and the voices of his actors" (Richard Linklater - Linklater's case)

"Some directors are tyrants, driving their actors with lengthy, chaotic shifts; abusing their crews; and running through assistants like silk stockings in a berry patch. This isn't Linklater's style" (interviewer - Linklater's Case)

Linklater also shot his Oscar-winning movie "Boyhood" across 12 years, to follow the evolution of the main character from the age of 5 to 18 . He did so by filming every 
Summer with the same cast for 12 years. Such an unusual filmmaking practice is undeniably part of the movie's success.

While Nolan is very demanding on set, he nonetheless tries to create a comfortable environment and leave room for experimentation:

"I really try to be different [and adapt] for every actor, I try to make them comfortable, I try to get the best out of them. You hear stories of directors deliberately making actors uncomfortable, but I always make the actor feel that they have what they need to explore a scene." (Christopher Nolan - Nolan's Case)

"I learned lots of things on Memento, but one thing I've always adhered to since then is letting actors perform as many takes as they want. I've come to realize that the lighting and camera setups, the technical things, take all the time, but running another take generally only adds a couple of minutes. If an actor tells me they can do something more with a scene, I give them the chance, because it's not going to cost that much time. It can't all be about the technical issues." (Christopher Nolan - Nolan's Case)

"With Insomnia, Al Pacino liked to rehearse very, very carefully, block things out, and do a lot of takes. His first take would be perfect, but he really wanted to talk about things, whereas Hilary Swank didn't want to rehearse too much. She wanted to save it, then do what she was going to do in one or two takes and no more. As a director, you have to figure out how to balance those things, because you want them both to feel that they're being given the floor in the way they need for what they're doing." (Christopher Nolan Nolan's Case)

Quentin Tarantino seems to dedicate extra-time building the character with actors, in order to be more effective on set: 
"Quentin briefs me on my character background for many weeks actually, he made me watch quite a few old movies, talk to me about what my character background would be" (actress - Tarantino’s case)

Other ways of organizing the filmmaking process that seem to favor more of a democratic process of integration is by establishing routines, learning routines and designing learning mechanisms. Those routines seem to enhance the collaborative context and creative output.

At Pixar, for example, John Lasseter has founded a body called the Braintrust, a team of long-timer, expert Pixar filmmakers, in charge of reviewing and critiquing Pixar's movies throughout the entire creative cycle:

"First we draw storyboards of the script and then edit them together with temporary voices and music to make a crude mock-up of the film, known as reels. Then the Braintrust watches this version of the movie and discusses what's not ringing true, what could be better, what's not working at all." (John Lasseter - Lasseter's case)

The goal of the Braintrust is to give feedback about Pixar movies under development:

"The Braintrust is fueled by the idea that every note we give is in the service of a common goal: supporting and helping each other as we try to make better movies." (coproducer -Lasseter's case)

“A good note doesn't make demands; it doesn't even have to include a proposed fix. But if it does, that fix is offered only to illustrate a potential solution, not to prescribe an answer." (co-producer - Lasseter's case)

Quentin Tarantino also uses some learning routines, as organizing Cine-forums, in order to foster creativity and collaboration among his team: 
"There is something which is quite incredible, Quentin organized a Cine-club every week, we saw lots of films from that period [World War II]" (actress - Tarantino's case)

\section{IMPLICATIONS}

The integrative creative leadership conceptualization focuses on "the leader's role in integrating his or her creative ideas with the diverse creative ideas of other professionals in the work context" (Mainemelis et al., 2015, p.398). Our investigation reveals a fairly wide continuum in the manner in which leaders combine their creative contributions with their followers'.

\section{Democratic Integration}

Factors that we hypothesize are associated with a more democratic form of integration include leaders involving followers early in the creative process, leaders demonstrating a relatively lower need for control, setting up structures and routines that enable collaboration and sharing, such as rehearsal time and Pixar's Brainstrust, tending to work with the same team across projects, and projects that are more technically complex. These findings are interesting in light of the debates in the literature about leadership styles and creativity. Some authors find that an empowering leadership style is positively linked with creativity, because it encourages employees' autonomy and freedom, while a directive leadership style appears negatively related to followers' creativity (Zhang et al., 2010). Creativity however, like many organizational phenomena, involves fundamental paradoxes (i.e. tensions between novelty and usefulness, idea generation and implementation, exploration and exploitation). A fundamental tension for the creation of something novel and useful is the need for both freedom and stability/structure in the process 
(Fortwengel et al., 2016; Cirella, 2016).

Creative leadership may therefore involve not only providing freedom, but also designing and sustaining structures and routines (Goncalo et al., 2015; Lampel et al., 2014; Cirella et al., 2016; Verganti, 2016). Concerning this challenge, we observe that leaders can design, manage and adopt a tapestry of learning mechanisms, i.e. a combination of conscious and planned engines that encourage collective learning and development (Popper and Lipshitz, 1998; Shani and Docherty, 2008). We also observed that utilizing design thinking is a powerful way to engage people in action by anchoring them directly into the creative process. Our findings provide an example of how this may happen. In integrative creative practices that are democratic, leaders provide freedom to their collaborators, but they also set up purposeful learning mechanisms by design in the form of structures and routines (such as Pixar's Braintrust and Linklater's early and long rehearsals).

\section{Autocratic Integration}

Factors that we hypothesize are associated with a more autocratic form of integration include leaders demonstrating a high need for control of the creative process, consolidating roles or master and overstepping on other professionals' roles, asking for secrecy, especially during the initial stages of the creative process, working with different crews across projects, involving others later in the process, having less time for improvisation and play, and having a less technologically complex process and a smaller crew. In integrative contexts, the creative character of the work is open to various interpretations and debates among collaborators throughout the creative process (Lampel \& Shamsie, 2003). Yet, our findings seem 
to imply that leaders on the autocratic end of the continuum seem averse to debating different creative interpretation of their work. This may be due to their high skills and competences (e.g. Tarantino on dialogues), but also their personal leadership style preference.

\section{CONCLUSION}

In this manuscript, we have identified some relevant insights about integrative creative leadership in the context of filmmaking. In particular, our examples highlight the likely existence of a continuum from autocratic to democratic integration, and identify factors possibly associated with variations on this continuum. While the integrative context of creative leadership implies collaboration among various heterogeneous professionals, such a collaboration does not necessarily imply democracy or equality. Integration can still occur in an autocratic manner. While we are agnostic about whether a more autocratic or more democratic approach to integration lead to higher or lower quality, or more innovative products, it would be interesting to explore this question in further studies. Another possible avenue for further research revolves around collective and shared leadership (e.g. Denis, Langley, \& Sergi, 2012; Friedrich et al. 2009; Pearce \& Conger, 2003), which have been presented as examples of integrative creative leadership (Mainemelis et al., 2015). It would be interesting to explore the relationship between formal and informal leaders (e.g. DP, screenwriter, costume designer, music composer) in the light of these theories. 


\section{REFERENCES}

Alvarez, J. L., Mazza, C., Pedersen, J. S., \& Svejenova, S. (2005). Shielding idiosyncracy from isomorphic pressures: Towards optimal distinctiveness in European filmmaking. Organization, 12, 863-888.

Alvarez, J. L., \& Svejenova, S. (2002). Symbiotic careers in movie making: Pedro and Augustin Almodovar. In M. Peiperl, M. Arthur, \& N. Anand (Eds.), Career creativity: Explorations in the remaking of work (pp. 183-208). New York, NY:

Oxford University Press.

Amabile, T.M. (1996). Creativity in context. Boulder, CO: Westview.

Barrett, F. J. (1998). Creativity and improvisation in jazz and organizations: Implications for organizational learning. Organization Science, 9, 605-622.

Basadur, M. S., Graen, G. B., \& Green, S. G. (1982). Training in creative problem solving: Effects on ideation and problem finding in an applied research organization. Organizational Behavior and Human Performance, 30, 41-70.

Bechky, B. A. (2006). Gaffers, gofers, and grips: Role-based coordination in temporary organizations. Organization Science, 17, 3-21.

Catmull, E., \& Wallace, A. 2014. Creativity, Inc: overcoming the unseen forces that stand in the way of true inspiration. Random House.

Cirella, S. (2016). Organizational Variables for Developing Collective Creativity in Business: A Case from an Italian Fashion Design Company. Creativity and Innovation Management, 25(3): 331-343.

Cirella, S., Canterino, F., Guerci, M., \& Shani, A.B. (2016). Organizational Learning Mechanisms and Creative Climate: Insights from an Italian Fashion Design Company. Creativity and Innovation Management, 25(2): 211-222.

Coget, J.F. 2004. Leadership in motion: An investigation into the psychological processes that drive behavior when leaders respond to "real-time" operational challenges. Unpublished doctoral dissertation. UCLA, Anderson School of Management.

Denis, J.-L., Langley, A., \& Sergi, V. (2012). Leadership in the plural. Academy of Management Annals, 6, 211-283.

Fortwengel, J., Schüßler, E. and Sydow, J. 2017. Studying Organizational Creativity as Process: Fluidity or Duality? Creativity and Innovation management. Volume 26, Issue 1, March 2017, Pages 5-16. 
Friedrich, T. L., Vessey, W. B., Schuelke, M. J., Ruark, G. A., \& Mumford, M. D. (2009). A framework for understanding collective leadership: The selective utilization of leader and team expertise within networks. Leadership Quarterly, 20, 933-958.

Goncalo, J. A., Chatman, J. A., Duguid, M. M., \& Kennedy, J. A. 2015. Creativity from Constraint? How the Political Correctness Norm Influences Creativity in Mixed-sex Work Groups. Administrative Science Quarterly, 60(1): 1-30.

Harris, T. B., Li, N., Boswell, W. R., Zhang, X. A., \& Xie, Z. 2014. Getting what's new from newcomers: Empowering leadership, creativity, and adjustment in the socialization context. Personnel Psychology, 67(3): 567-604.

Halbesleben, J. R. B., Novicevic, M. M., Harvey, M. G., \& Buckley, M. R. (2003). The influence of temporal complexity in the leadership of creativity and innovation: A competency-based model. Leadership Quarterly, 14, 433-454.

Lampel, J., Honig, B., \& Drori, I. 2014. Organizational Ingenuity: Concept, Processes and Strategies. Organization Studies, 35(4): 465-482.

Lampel, J., \& Shamsie, J. (2003). Capabilities in motion: New organizational forms and the reshaping of the Hollywood movie industry. Journal of Management Studies, 40, 2189-2210.

Lovelace, J. B., \& Hunter, S. T. 2013. Charismatic, Ideological, and Pragmatic Leaders' Influence on Subordinate Creative Performance Across the Creative Process. Creativity Research Journal, 25(1), 59-74.

Lumholdt, J. (2003). Lars von Trier: interviews. University Press of Mississippi.

Mainemelis, C. (2002). Time and timelessness: Creativity in (and out of) the temporal dimension. Creativity Research Journal, 14, 227-238.

Mainemelis, C., \& Altman, Y. (2010). Work and play: New twists on an old relationship. Journal of Organizational Change Management, 23, 4-9.

Mainemelis, C., \& Dionysiou, D. (2015). Play, flow, and timelessness. In C. Shalley, M. Hitt, \& J. Zhou (Eds.), The Oxford Handbook of creativity, innovation, and entrepreneurship (pp. 121-140). New York, NY: Oxford University Press.

Mainemelis, C., Kark, R., \& Epitropaki, O. 2015. Creative leadership: A multi-context conceptualization. The Academy of Management Annals, 9(1): 393-482.

Mumford, M.D., Medeiros, K.E., Partlow, P.J. 2012. Creative Thinking: Processes, Strategies, and Knowledge. Journal of Creative Behaviour, Vol. 46, pp. 30-47.

Murphy, S.E., Ensher, E.A. 2008. A qualitative analysis of charismatic leadership in 
creative teams: The case of television directors. The Leadership Quarterly, 19:335-352.

Pearce, C. L., \& Conger, J. A. (2003). Shared leadership: Reframing the hows and whys of

leadership. Thousand Oaks, CA: Sage.

Popper, M. and Lipshitz, R. (1998). Organizational Learning Mechanisms: A Structural and Cultural Approach to Organizational Learning. Journal of Applied Behavioral Science, 34(2), 161-179.

Reiter-Palmon, R., \& Illies, J. J. 2004. Leadership and creativity: Understanding leadership from a creative problem-solving perspective. The Leadership Quarterly, 15(1): 55-77.

Shani, A. B. and Docherty, P. (2008). Learning by Design: Key Mechanisms in Organization Development. In T. Cummings (Ed.), Handbook of Organizational Change and Development (pp. 499-518). Thousand Oaks, CA: Sage.

Svejenova, S. (2005). "The path with the heart": Creating the authentic career. Journal of Management Studies, 42, 947-974.

Vera, D., \& Crossan, M. (2004). Theatrical improvisation: Lessons for organizations. Organization Studies, 25, 727-751.

Verganti, R., (2016), Overcrowded: Designing Meaningful Products in a World Awashed with Ideas. Cambridge, Mass.: The MIT Press.

Zhang X., Bartol K.M. 2010. Linking empowering leadership and employee creativity: The influence of psychological empowerment, intrinsic motivation, and creative process engagement. Academy of Management Journal, 53: 107-128. 